\title{
SIZE AND CHARACTERISTICS OF AGGREGATIONS OF MOON JELLYFISH (AURELIA SP.) IN TASMANIA, AUSTRALIA
}

\author{
by Christine M. Crawford, Natalie A. Moltschaniwskyj and Simon Willcox
}

(with four text-figures, one plate and one table)

\begin{abstract}
Crawford, C.M., Moltschaniwskyj, N.A. \&Willcox, S. 2011 (9:xii): Size and characteristics of aggregations of moon jellyfish (Aurelia sp.) in Tasmania, Australia. Papers and Proceedings of the Royal Society of Tasmania 145: 9-16. https://doi.org/10.26749/rstpp.145.9 ISSN 0080-4703. Fisheries, Aquaculture \& Coasts, Institute of Marine and Antarctic Studies, University of Tasmania, PO Box 49, Sandy Bay, Tasmania 7001, Australia. (CMC*); School of Environmental and Life Sciences, Chemistry Building - C218, University of Newcastle, University Drive, Callaghan, NSW 2308, Australia (NAM); EPA Division, Department of Primary Industries, Parks, Water and Environment, 134 Macquarie Street, Hobart, Tasmania 7000, Australia (SW). * Author for correspondence. Email: Christine.Crawford@utas.edu.au
\end{abstract}

Dense aggregations of moon jellyfish, Aurelia sp., occurred in four of eight summers from 1978/79 to 2004/05 in the Huon Estuary, southern Tasmania, causing significant mortality of farmed Atlantic Salmon. This study investigated the biological characteristics of this jellyfish as part of a larger study examining factors influencing these aggregation events. Aggregations of medusae in the Huon Estuary were intensively sampled over 50 days in 2004/05. They typically had a strongly delineated structure throughout the water column, with a relatively high density of medusae at maturity, then the aggregations rapidly disappeared (size at maturity for $50 \%$ of the population was $101 \mathrm{~mm}$ bell diameter for females, $90 \mathrm{~mm}$ bell diameter for males). The discrete structure of the aggregations enabled relatively accurate estimates of the biomass of the Aurelia sp. population when growth rate was at its maximum. The number of aggregations in the estuary, their sizes and density of medusae were estimated from aerial photographs, by divers, and underwater video records. Mean density in the aggregations was 71 medusae $\mathrm{m}^{-3}$. They contained approximate totals of $174 \mathrm{million}$ Aurelia sp. medusae, wet weight of $28,600 \mathrm{t}$, and $39.2 \mathrm{t}$ of carbon. Our observations suggest that the main advantage of forming these complex aggregations is to enhance fertilisation success. Key Words: Aurelia sp., jellyfish blooms, aggregations, density, reproduction, Huon River, Tasmania.

\section{INTRODUCTION}

Moon jellyfish, Aurelia spp., are found in marine and estuarine environments worldwide and can concentrate into dense aggregations within enclosed or semi-enclosed water bodies (e.g., Lucas et al. 1997, Purcell et al. 2000). Aggregations are often promoted by physical properties of the water body in which they occur and are commonly believed to facilitate sexual reproduction, rather than act as a defence against predation or targeting food sources (Graham et al. 2001, Lucas 2001). The presence of large-scale aggregations of medusae, as a function of favourable conditions, has substantial ecological and economic consequences (Purcell et al. 2007).

The distribution, abundance and life history characteristics of the genus Aurelia are highly variable spatially and temporally (e.g., Schneider \& Brehrends 1994, Lucas et al. 1997). The pelagic medusa stage generally occurs seasonally and lives for several months (Lucas \& Williams 1994, Miyake et al. 1997), but in some populations, medusae will live for 12 months or more (Kinoshita et al. 2006).

Aurelia medusae are voracious feeders and are capable of modifying the seasonal composition and abundance of the planktonic community (Schneider \& Brehrends 1994, Lucas et al. 1997). Secondary effects of high grazing pressure include increased phytoplankton biomass through reduced grazing pressure by copepods (Lindahl \& Hernroth, 1983, Olsson et al. 1992, Møller \& Riisgård 2007a) and decreased food availability for other zooplanktivores, which can have impacts through the food chain (Purcell \& Arai 2001). Given their widespread distribution, occurrence in large aggregations and capacity to alter trophic dynamics, jellyfishes are potentially important consumers and transformers of energy and nutrients in the marine ecosystem (e.g., Watanabe \& Ishii 2001, Pauly et al. 2009, Pitt et al. 2009).
Determining the abundances and sizes of jellyfish in the oceans has proved difficult because of their large sizes, fragility and patchy distributions, both horizontally and vertically, and because their gelatinous bodies are difficult to tag (Purcell 2009). Also, the high water content of their tissues makes acoustic sampling difficult, although combined acoustic soundings and video recordings can monitor relatively reliably some jellyfish species, provided the target species can be distinguished from other co-occurring species acoustically (Båmstedt et al. 2003, Alvarez Columbo et al. 2009). Consequently, estimates of the extents, causes and effects of jellyfish blooms have rarely been conducted on a large scale (Purcell 2009).

Aurelia sp. medusae periodically occur in dense monospecific aggregations in the sheltered waterways of southeast Tasmania, Australia (pl. 1). The medusae are morphologically similar to Aurelia aurita; however, they are genetically distinct from other species of Aurelia and have been designated as Aurelia sp. 7 (Dawson et al. 2005).

Growth, survival and reproduction of the sessile, asexual, colonial phase of this species has been found to be regulated by a combination of density-dependent factors and environmental conditions, which are consequently important to the formation of jellyfish aggregations (Willcox et al. 2008). These aggregations, however, were largely unnoticed until they caused the deaths of cultured Atlantic Salmon in Tasmania, valued at millions of dollars. 'The objective of this study was to describe the biological characteristics of this species, as part of a larger study investigating mechanisms driving the intermittent occurrence of Aurelia sp. aggregations in southeast Tasmania. This included growth and reproduction of individuals in the aggregations, and estimating aggregation size and total biomass of medusae in the system. To achieve this, we developed a method to assess 


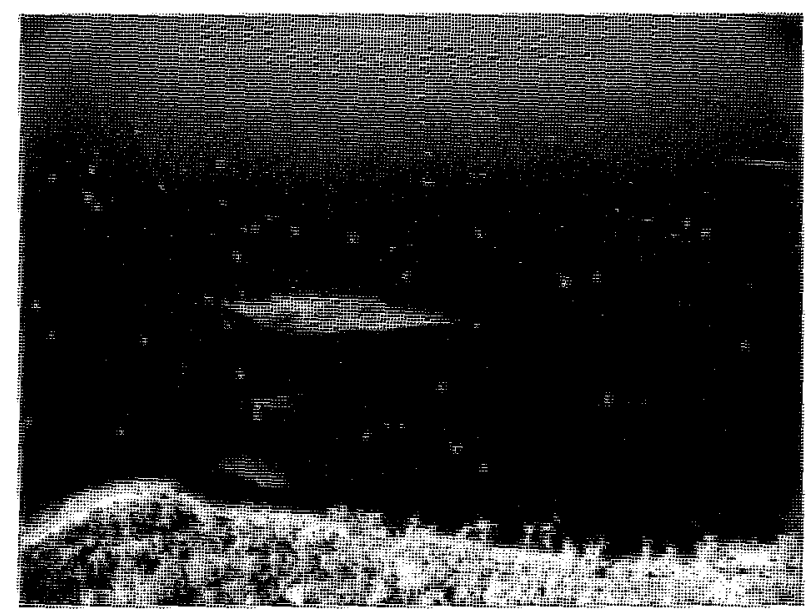

PLATE 1

Bloom of Aurelia sp. in the Huon Estuary, Tasmania, as viewed from a light plane at $1000 \mathrm{ft}$.

the abundance of jellyfish by combining aerial photography, underwater video photography and net sampling.

\section{MATERIALS AND METHODS}

The abundance of Aurelia sp. medusae and macrozooplankton in the Huon Estuary in southern Tasmania was estimated from plankton samples taken at three locations: $\mathrm{H} 1, \mathrm{H} 3$ and $\mathrm{H} 12$ (fig. 1) every 4--6 weeks from March 2001 to March 2003 and every $1-3$ weeks when medusae were abundant. Samples were collected using a $65 \mathrm{~cm}$ diameter bongo net with 500 $\mu \mathrm{m}$ and $315 \mu \mathrm{m}$ mesh fitted with General Oceanics flow meters. We used larger-than-standard mesh for zooplankton to sample large volumes of water for Aurelia sp. ephyrae and small medusae. Plankton tows were oblique from $10 \mathrm{~m}$ to the surface at a constant speed of 2-3 knots for $3 \mathrm{~min}$ at each location; abundances were standardised as numbers per litre.

\section{Bloom population dynamics}

Dense aggregations of Aurelia sp. medusae were found only over a 2-month period, from December 2002-January 2003 in a $10-\mathrm{km}$ section of the Huon Estuary (fig. 1). Ten aggregations of moon jellyfish were randomly selected and observed on seven separate days in January 2003. A small boat equipped with a GPS mapping system, echo sounder and underwater camera were used to locate and determine the size, shape and depth distribution of the aggregations. Medusae were sampled from randomly selected aggregations during daylight hours using a $40 \mathrm{~cm}$ diameter $1 \mathrm{~mm}$ mesh plankton net fitted with a General Oceanics flow meter. Oblique tows from $-5 \mathrm{~m}$ depth at a constant speed of $0.5-1.5$ knots were made within aggregations for 30-180 s, depending on density of medusae. A sub-sample of 20-30 medusae was examined alive and another $20-30$ were preserved in buffered $4 \%$ formalin for assessment of maturity.

The bell diameter (BD in $\mathrm{mm}$ ) of each medusa was measured as the distance between the tips of opposite rhopalia (marginal sense organs). The amount of shrinkage (reduction in BD) during preservation was estimated by measuring $\mathrm{BD}$ on 30 live medusae before they were stored in $4 \%$ formalin, and then again after 22 weeks in preservative, giving the relationship:

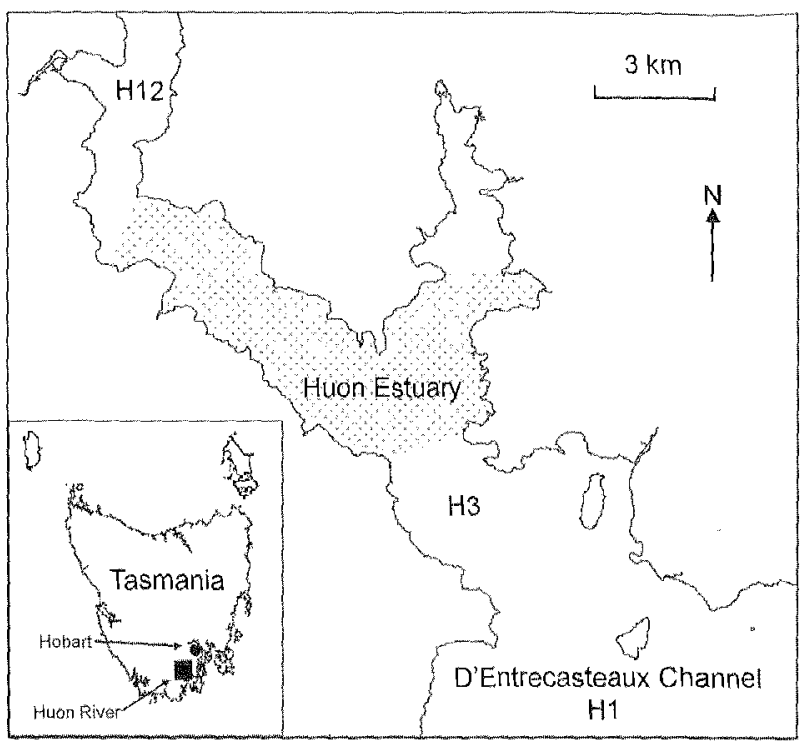

FIG. 1 - Location of the Huon Estuary in southeast Tasmania, Australia. The stippled area shows the section of the estuary where medusa aggregations were observed during the summer of $2002 / 03$.

$$
\mathrm{BD}_{(\text {live })}=1.22 * \mathrm{BD}_{\text {(preserved) }}\left(\mathrm{n}=30, \mathrm{R}^{2}=0.65\right)
$$

All preserved BD measurements were adjusted by this relationship to give the live $\mathrm{BD}$ for data analysis. Wet weight (WW) was measured to the nearest gram after medusae were lightly shaken to remove excess water. The relationship between WW and BD was represented by the equation:

$$
\mathrm{WW}=1.12 \times 10^{-4 *} \mathrm{BD}^{2.81}\left(\mathrm{n}=305, \mathrm{R}^{2}=0.97\right) \text {. }
$$

We measured dry weight (DW in g) after drying medusae to a constant weight at $50^{\circ} \mathrm{C}$ (Larson 1986); DW was $3.7 \%$ of WW. Accurate measurement of medusa DW is difficult because bound water is retained after drying (Larson 1986, Doyle et al. 2007); our measure is similar to that recorded by Uye \& Shimauchi (2005) for Aurelia aurita in the Inland Sea of Japan. We converted DW to carbon content $(\mathrm{C})$ with the relationship $\mathrm{C}=3.6 \% \mathrm{DW}$ in Uye $\&$ Shimauchi (2005), which was determined at salinities $>30$, as found in the Huon Estuary. Conversions involving DW and $C$ differ depending on ambient salinity and this conversion may provide a conservative estimate of carbon content because the ratio of C:DW is lower than values tabulated for Aurelia spp. in lower salinities (Purcell 2009).

Growth rate of medusae was calculated by fitting an exponential relationship to $\mathrm{BD}$ data, with strobilation predicted to have occurred on 1 October 2002, based on strobilation occurring in late August to early October in 2003 and 2004 (Willcox et al. 2008). Mean ephyra BD was assumed to be $2 \mathrm{~mm}$ on strobilation (Båmstedt 1990). Using this initial size at strobilation and the size data for medusae collected from 5 December 2002-31 January 2003, the average $B D$ was used to estimate a rate of growth over the spring and summer. However, measurements of BD from the last two days of sampling showed a changed growth pattern and were not included in the growth equation. Those animals were drifting down the estuary near the surface and were the only remaining medusae found. Mean daily 
growth rate was calculated for each period on the basis of increments in $\mathrm{BD}$ :

$$
\text { Growth }=\frac{B D_{2}}{\Delta t} \frac{-B D_{1}}{1}
$$

where $B D_{1}$ and $B D_{2}$ are the mean bell diameters for each period, and $\Delta t$ is the number of days between the two collection times. Estimates of growth of individuals in the population using a modal size progression analysis (Palomares \& Pauly 2009) was not possible because the data were collected intensively over several weeks and not over months or years; size also increased very rapidly and did not attain an asymptote.

Sex and maturity stage were defined as:

Juvenile (j): gonad thin, clear, indistinguishable as male or female;

Immature male (im): gonad clear/opaque, spermatogenic follicles beginning to form in the epithelium;

Mature male (mm): gonad dark pink/purple, follicles well developed;

Immature female (if): gonad clear/opaque, developing oocytes visible, large late-stage oocytes few or absent;

Mature female ( $\mathrm{mf})$ : gonad opaque pink/purple, many large late-stage oocytes;

Brooding female (bf): gonad as for MF, with fertilised eggs and planula larvae in brood pouches on oral arms.

Gonads from a total of 39 mature and brooding females over five sampling days (January 19, 20, 22, 24 and 30) were examined. The diameters of an arbitrary selection of approximately 100 oocytes from each female were measured with an ocular micrometer on a microscope at $50 \mathrm{x}$ power. Differences in oocyte size frequency distributions among the five days were compared using a $\chi^{2}$ test of independence. A logistic model of proportional maturity at length using maximum likelihood estimation assuming a binomial error distribution (Quinn \& Deriso 1999) was fitted to the data to determine the BD at which 50\% (s50) and 95\% (s95) of male and female medusae were mature.

\section{Aggregation numbers and sizes}

The total population of Aurelia sp. in the Huon Estuary and adjacent waters was estimated from an aerial survey of aggregations on the afternoon of 23 January 2003 at altitudes of 300-1500 m (method modified from Purcell et al. 2000; Graham et al. 2003). Low oblique photographs were taken of each aggregation and geographical features were included (e.g., points, bays, boat ramps, fish farms, roads, houses) for size calibration. Cameras were fitted with filters to remove the effect of glare (Houghton et al. 2006). Images were geo-rectified (Wolf \& Dewitt 2000) to fit a scale map of the Huon Estuary and aggregation outlines were digitised and the surface area calculated. We confirmed that aggregations observed from the air were Aurelia sp. medusae on the day of the aerial survey with a small boat equipped with an underwater camera. A random search of the estuary using the echo sounder and underwater camera did not find any aggregations that were not visible from the air.

The vertical distribution of aggregations observed in the aerial survey on 23 January 2003 was assumed to be similar to the observations and measurements of aggregations in the Huon Estuary made by divers, underwater cameras and echo-sounders on each sampling day in January 2003. Water depth at the location of each aggregation was determined from bathymetric charts and the number of medusae in each aggregation was estimated from the mean density of medusae in aggregations ( $n=4$ over 3 days) measured with a $40 \mathrm{~cm}$ diameter $1 \mathrm{~mm}$ mesh plankton net as above on three consecutive days, i.e., the days before, on and after the aerial photographs were taken.

\section{RESULTS}

\section{Bloom population dynamics}

Aurelia sp. medusae were found in large dense aggregations in the Huon Estuary in southeast Tasmania only during the summer of $2002 / 03$ in water temperatures ranging from $16.1-17.5^{\circ} \mathrm{C}$ and salinities of $32.8-34.0$ at $1 \mathrm{~m}$ depth in the middle estuary. Medusae were first collected on 5 December 2002 when mean bell diameter (BD) was 24.6 $\mathrm{mm} \pm 5.88$ (standard error). BD of medusae sampled from the aggregations increased exponentially from 1 October 2002-24 January 2003 according to the equation BD $(\mathrm{mm})=$ $\mathrm{e}^{0.042^{*} \text { days }}$, equivalent to an increase of $4.2 \% \mathrm{BD} \mathrm{d}^{-1}$ (fig. 2). Maximum mean size $(171.8 \pm 17.6 \mathrm{~mm})$ was reached on 24 January and the largest medusa sampled was $246 \mathrm{~mm}$. This peak was followed by a seven-day period when the mean $B D$ of individuals in the population decreased and all medusae observed showed disintegration of the marginal region.

Fifty percent of female Aurelia sp. medusae reached maturity at $101 \mathrm{~mm} \mathrm{BD}$ and $95 \%$ at $125.6 \mathrm{~mm}$. Fifty percent of males reached maturity at $90 \mathrm{~mm} \mathrm{BD}$ and $95 \%$ at $131 \mathrm{~mm}$. Maturity was not as tightly constrained by size in males as it was in females, which had a larger difference in BD between 50\% maturity and 95\% maturity. The maturity stage distribution of females in the aggregations differed significantly over January $\left(\chi^{2}=28.03\right.$, degrees of freedom $(\mathrm{df})=5, \mathrm{P}<0.001)$, with the proportion of mature females in the population increasing through time (fig. 3). The first mature medusae were seen on 19 January when $78 \%$ of males and $65 \%$ of females were mature. By 30 January (day 56) $100 \%$ of males and $89 \%$ of females were mature. The proportion of females carrying planula larvae (bf) increased in during January (fig. 3). The sex ratio over

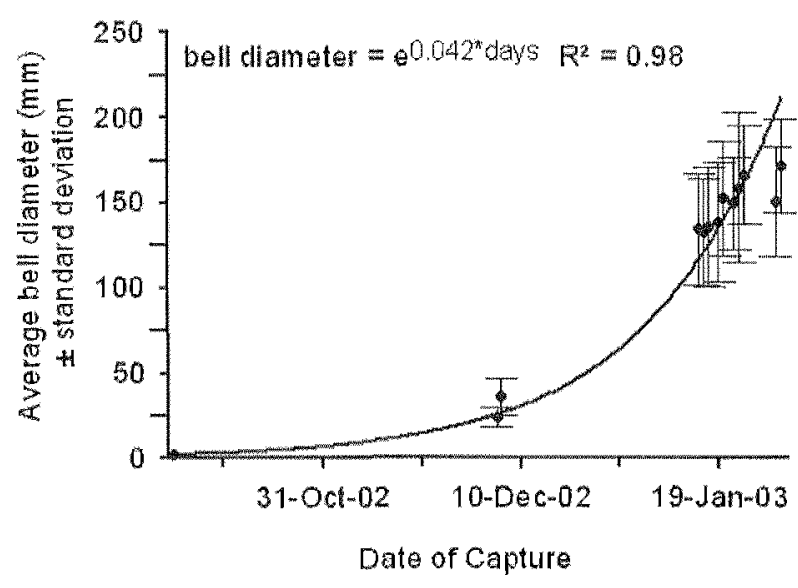

FIG. 2-Changes in average bell diameter (BD) (with standard deviation) of Aurelia $s p$. medusae in the Huon Estuary from 1 October 2002-31 January 2003, n=645 individuals. The size of the ephyra on 1 October 2002 (the first data point) was estimated from the literature (Bamstedt 1990). The fitted line describes an exponential increase in average bell diameters. 

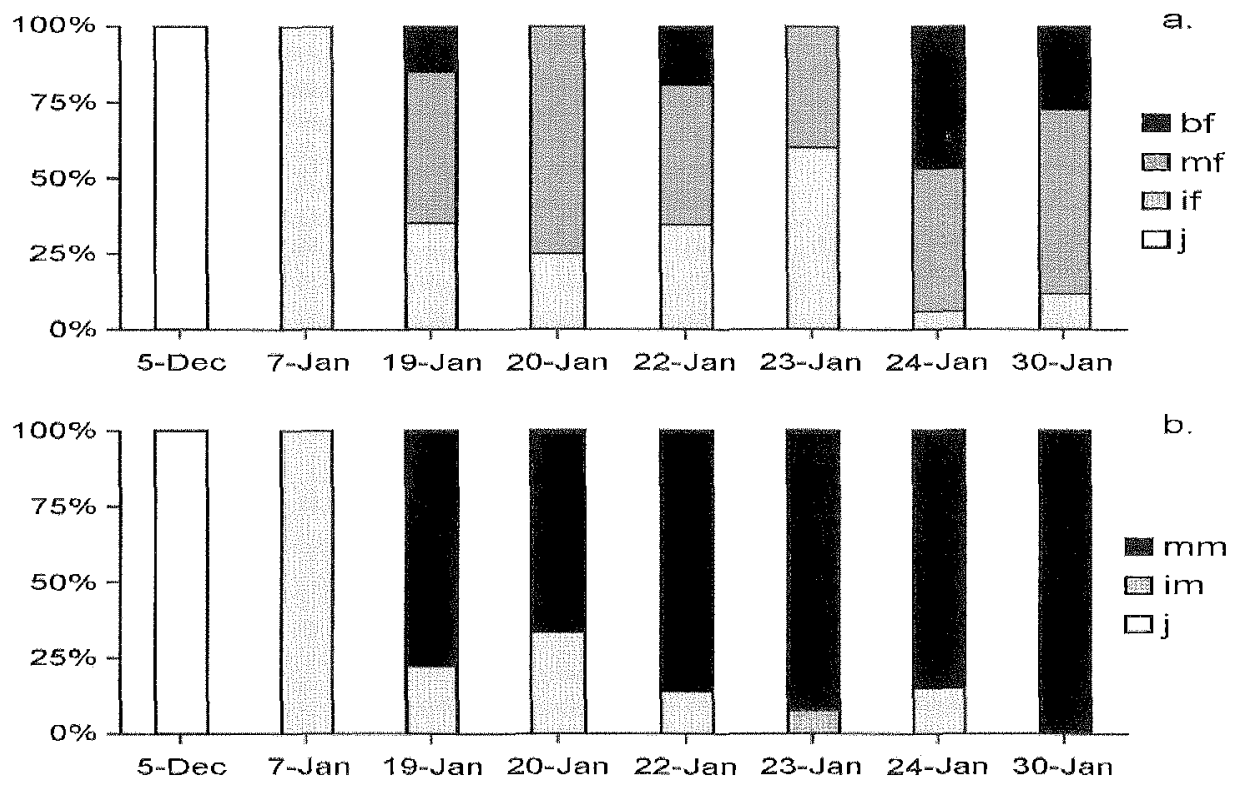

FIG. 3 - Percent frequency of the maturity stages for the Aurelia sp. population on each sampling day for a) fermale medusae ( $j=j$ juvenile, if $=$ immature, $m f=$ mature, $b f=$ brooding), and $b$ ) male medusae ( $j=j$ juvenile, im=immature, $m m=$ mature) in the Huon Estuary in the summer of 2002/03.

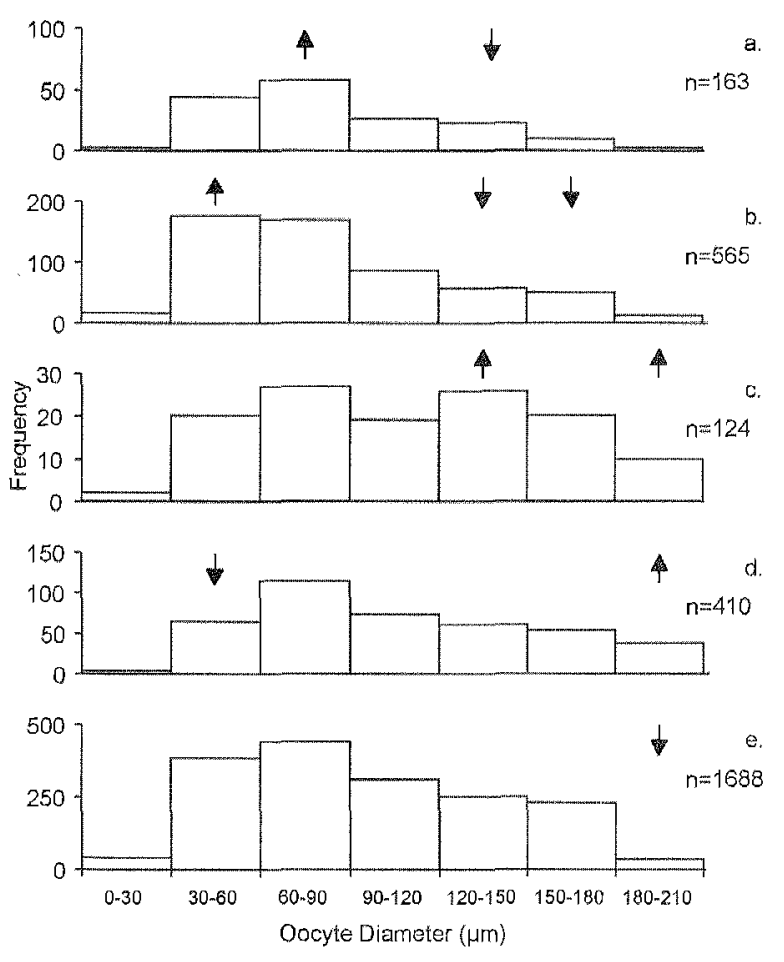

FIG. 4 - Aurelia sp. oocyte size frequency distributions for mature medusae from the Huon Estuary. (a) 19 January (4 medusae), (b) 20 January (7 medusae), (c) 22 January (4 medusae), (d) 24 January (6 medusae), (e) 30 January (18 medusae). Arrows indicate the size class that had more $(\uparrow)$ or fewer $(\downarrow)$ oocytes than expected if the size distributions were the same on each sampling occasion. $n=$ number of oocytes measured. the summer was approximately $1: 1$, although there was some fluctuation among days during the season. The proportion of males was only $25 \%$ on day 56 , the last day of sampling.

There was a significant difference in the size frequency distribution of oocytes through time $\left(\chi^{2}=140.8, \mathrm{df}=24, \mathrm{P}\right.$ $<0.001)$, with mature female gonads containing more small oocytes than expected on 19 January and more large mature oocytes than expected one week later when the jellyfish were at maximum size (fig. 4). On the last sampling day (56) of the season, the oocytes in the gonads predominately were immature and those medusae were beginning to disintegrate; the large, discrete aggregations previously sampled could not be located.

\section{Aggregation number and size}

Aggregations generally had very sharp, planar boundaries $( \pm 12 \mathrm{~m})$ on all sides including the top and bottom. The tops of aggregations were readily visible from the surface and were $1-3 \mathrm{~m}$ below the surface during relatively stable sea state conditions. Observations by both underwater camera and divers suggested that the aggregations were of uniform density throughout the water column; however, density was not measured at discrete locations within aggregations to confirm this impression. The bottom boundaries of aggregations paralleled the sea floor 1-3 $\mathrm{m}$ above the bottom. Densities of medusae in the aggregations over the sampling period ranged from $18-270 \mathrm{~m}^{-3}$ with an average of $133 \pm$ 37.2 medusae $\mathrm{m}^{-3}$.

A total of 22 aggregations were observed and photographed in the lower Huon Estuary during an aerial photography flight on day 49. These aggregations were clearly visible from the air, appeared pale green in colour (pl. 1) and ranged from circular to elliptical in shape. We assumed that all aggregations in the estuary were visible at the surface at the time of the flight because all aggregations of Aurelia sp. detected over the summer by visual and acoustic methods 
and plankton nets extended from about $1.5 \mathrm{~m}$ above the bottom to within about $1.5 \mathrm{~m}$ of the surface and were clearly visible from the boat during daylight and stable sea state conditions.

The mean density of medusae in four aggregations was estimated to be $71 \pm 32.7 \mathrm{~m}^{-3}$ based on plankton tows in the aggregations on three days. The largest aggregation observed during the summer had a volume $>600000 \mathrm{~m}^{3}$ and contained an estimated 100 million individuals. The largest aggregation on the day of the aerial survey was estimated to be $233000 \mathrm{~m}^{3}$ with an estimated 23 million medusae. The smallest aggregation measured was $5200 \mathrm{~m}^{3}$ and contained approximately 370000 individuals.

On 23 January, the total estimated volume of aggregations in the Huon Estuary was 2.46 million $\mathrm{m}^{3}$. The total number of medusae in the aggregations was estimated to be 174.4 million with a WW of 28600 metric tons $(\mathrm{t})$ incorporating $39.2 \mathrm{t}$ of carbon (table 1). By use of the Uye \& Shimauchi (2005) estimate of $9.2 \%$ as a likely mean daily specific carbon ration, determined from field studies of gut content for $A$. aurita of comparable size range and at similar salinities to Aurelia sp. in the Huon Estuary, it was estimated that the whole population would have consumed about $3.6 \mathrm{t} \mathrm{C} \mathrm{d}^{-1}$ (table 1). Alternatively, by use of the respiration equation for Aurelia spp. medusae in Purcell (2009), the minimum daily specific ration would be $-6.4 \%$, or about $2.4 \mathrm{t} \mathrm{C} \mathrm{d}^{-1}$.

\section{DISCUSSION}

\section{Bloom population dynamics}

The occurrence of Aurelia sp. medusae in southeast Tasmania followed an annual cycle with recruitment of medusae in early spring followed by exponential growth over summer. Assuming ephyrae were produced at a similar time of year in 2002 to when they were observed being released from a polyp colony in the D'Entrecasteaux Channel (fig. 1) in 2003 and 2004 (Willcox et al. 2008), growth was slow initially before the observed exponential growth in warmer summer waters. This growth pattern is typical of many Aurelia species populations (e.g., Schneider \& Behrends 1994, Lucas 2001, Uye \& Shimauchi 2005). Towards the end of the 2002/03 summer the positive growth of medusae ceased and the condition of medusae deteriorated. Within 10 days of maximum medusae size, the large aggregations were absent

TABLE 1

Aurelia sp. estimates of bloom size and food
requirements of medusa in the Huon Estuary on
23 January 2003

\begin{tabular}{ll}
\hline Parameter & \multicolumn{1}{c}{ Estimated values } \\
\hline Total volume of aggregations & $2456696 \mathrm{~m}^{3}$ \\
Mean density & $71+32.7$ medusae. $\mathrm{m}^{-3}$ \\
Total number of medusae & 174.4 million \\
Wet weight biomass & 28600 tons \\
Dry weight biomass & 1058 tons \\
Total carbon & 39.2 tons \\
Estimated daily carbon ration & $2.4-3.6$ metric tons day \\
\hline
\end{tabular}

and no medusae were observed. This rapid growth pattern followed by sudden disappearance of medusa is not suited to length-frequency analysis of growth, although this method of assessment of growth has been recommended for longer lived Aurelia sp. populations (Palomares \& Pauly 2009).

The availability of sufficient food is critical to sustaining the growth and condition of other species of Aurelia (Olesen et al., 1994, Lucas et al. 1997, Ishii \& Tanaka 2001). The biomass of mesozooplankton sampled in the $315 \mu \mathrm{m}$ mesh net peaked in abundance at the same time as the medusae in January 2003 in the Huon Estuary (Willoox 2006). Aurelia sp. medusae size, growth rate, deterioration and disappearance tracked the zooplankton biomass with a lag of 5-10 days, which suggests a strong link between food supply and Aurelia sp. growth and maturation; however, Aurelia spp. medusae also consume small prey, including microzooplankton (Uye \& Shimauchi 2005, Malej et al. 2007, Purcell 2009), which were not sampled in our study. Nevertheless, the growth of medusae may have been affected by a reduction in food availability in the Huon Estuary. It was not possible to determine whether the decline in large zooplankton biomass in the Huon Estuary was due to predation by medusae. Dense populations of scyphozoans can reduce zooplankton biomass (e.g., Schneider \& Behrends 1994, Lucas et al. 1997), and decreases in growth rate after a fast initial rate often result from changes in the environment induced by the organisms themselves (Coyne 1973).

The reduction in size of individuals in the aggregation is indicative of negative growth of the medusae and is characteristic of $A$. aurita; they survive through periods of low food availability by using resources held in body tissues (Hamner \& Jenssen 1974, Lucas 2001). Negative growth of up to $70 \%$ reduction in size after 100 days of starvation can occur (Hamner \& Jenssen 1974). Slowed growth of A. aurita in summer may not be due to food limitation, but to energy re-allocation from somatic to reproductive growth (Lucas 2001); however, in our study, large proportions of males and females were fully mature before growth rates slowed. Negative growth following gamete release was observed by Ishii \& Tanaka (2001), who concluded that the reduction in medusa size was independent of food availability. The apparent reduction in growth of Aurelia sp. may have been due to the disappearance or death of large individuals after gamete release.

An abrupt decline in numbers is relatively common in jellyfish populations (e.g., Uye \& Shimauchi 2005, Titelman et al. 2006) and may occur due to senescence following spawning (Mills 1993, Lucas 2001), whole-animal predation, grazing by predators and parasites/symbionts, such as hyperiid amphipods (Gröndahl 1988, Mills 1993), sudden unusual hydrographic events and hydraulic processes (Møller \& Riisgård 2007b), or lack of food. Although "spent" female gonads were not observed at the end of the season, the highest percentage of females with planula larvae in the gonads was captured on day 49 when medusa size peaked. After that time, few medusae were caught and their condition had deteriorated, suggesting that spent animals rapidly disappeared and the last jellyfish sampled were among the few remaining to spawn. The death of animals with remaining reproductive potential is common among short-lived species with indeterminate life spans (Stearns 1992). There was no evidence of an influx of parasites towards the end of the season. 


\section{Aggregation number and size}

The aggregations formed by Aurelia sp. in the Huon Estuary were mostly very distinct with sharp vertical boundaries extending from the surface to the bottom; they each formed a "wall" of jellyfish that moved within the estuary. Aggregations maintained their discrete structure with high and relatively uniform jellyfish density over many hours despite the upper and lower layers of the water column moving in different directions. This was achieved by a highly complex pattern of active, coordinated movement of medusae throughout the aggregations (Willcox 2006). Evolutionary advantages to aggregation were suggested by Hamner et al. (1994), Purcell et al. (2000) and Rakow \& Graham (2006) as increased fertilisation success or retention in convergences where zooplankton prey are concentrated. Other suggestions include retention in inshore waters near suitable sites for settlement of planktonic larvae and reduction in predation (Purcell etal. 2000 ), or that groups of medusae orient to currents to avoid damaging levels of sheer and turbulence (Rakow \& Graham 2006). Our observations of aggregations in the Huon Estuary suggest that they would enhance reproductive success, as evidenced by the high levels of brooding females and the rapid disappearance of the aggregations after most jellyfish reached maturity. These aggregations also would maintain spawning jellyfish within the estuary, which has strong tidal currents, surface freshwater flows and short flushing time, near substrates suitable for settlement of planula larvae. Avoidance of predation appears to be of low importance in this area because no predators of jellyfish are known to occur in sufficient quantities in the region to warrant the maintenance of aggregations. There was no evidence of directional movement of aggregations (Willcox 2006), suggesting that the synchronised activity of individuals may be more important to maintain the aggregation structure than to facilitate their location in areas of higher prey abundance.

Aurelia spp. are tolerant to a wide range of environmental conditions and display great plasticity in their population structure. Populations of Aurelia sp. in southeastern Tasmania also are characterised by interannual variability in the occurrence of aggregations, by having a strongly delineated aggregation structure throughout the water column, relatively high density of large medusae at maturity and rapid disappearance with no records of strandings. The discrete structure of the aggregations with vertical walls of jellyfish to within 1-3 m of both the surface and the bottom provided the rare opportunity to estimate the biomass of the moon jellyfish population in the Huon Estuary when growth rate was at its maximum, with a relatively high level of accuracy. The estimated WW biomass of 28600 tons and daily $C$ ration of 2.4-3.6 $\mathrm{t} \mathrm{d}^{-1}$ provides an approximation of medusa grazing pressure in the estuary. The effects of this large Aurelia sp. biomass on the Huon Estuary ecosystem are unknown; however, it is likely that they modify the flow of energy and nutrients through the local ecosystem (e.g., Ishii \& Tanaka 2001, Uye \& Shimauchi 2005). Further studies on the compounding effects of Aurelia sp. blooms at different trophic levels are required; however; these aggregation events occur sporadically.

\section{ACKNOWLEDGEMENTS}

We thank the initially four, and after amalgamations, two salmon farming companies, Tassal Ltd and Huon Aquaculture Pty Ltd for their financial support, sharing of information and logistical support on the water. This research was funded by an Australian Research Council Linkage grant to C.M.C and N.A.M.

\section{REFERENCES}

Alvarez Columbo, G., Benović, A., Malej, A., Lučić, D., Makovec, T., Onofri, V., Acha, M., Madirolas, A. \& Mianzan, H. 2009: Acoustic survey of a jellyfishdominated ecosystem (Mljet Island, Croatia). Hydrobiologia 616: 99-111.

Bamstedt, U.S., 1990: Trophodynamics of the scyphomeduae Aurelia aurita, predation rate in relation to abundance, size and type of prey organism. Journal of Plankton Research 12: $215-229$.

Båmstedt, U., Kaartvedt, S. \& Youngbluth, M. 2003: An evaluation of acoustic and video methods to estimate the abundance and vertical distribution of jellyfish. Journal of Plankton Research 25: 1307-1318.

Coyne, J.A. 1973: An investigation of the dynamics of population growth and control in scyphistomae of the scyphozoan Aurelia aurita. Chesapeake Science 14: 55-58.

Dawson, M.N., Sen Gupta, A. \& England, M.H. 2005: Coupled biophysical global ocean model and molecular genetic analyses identify multiple introductions of cryptogenic species. Proceedings Natural Academy of Science USA 102: $11968-11973$.

Doyle, T.K., Houghton, J.D.R., McDevitt, R., Davenport, J. \& Hays, G.C. 2007: The energy density of jellyfish: Estimates from bomb-calorimetry and proximate-composition. Journal of Experimental Marine Biology and Ecology 343: 239-252.

Graham, W.M., Pagès, F. \& Hamner, W.M. 2001: A physical context for gelatinous zooplankton aggregations: a review. Hydrobiologia 451: 229-246.

Graham, W.M., Martin, D.L., Felder, D.L., Asper, V.I. \& Perry, H.M. 2003: Ecological and economic implications of a tropical jellyfish invader in the Gulf of Mexico. Biological Invasions 5: 53-69.

Gröndahl, F. 1988: A comparative ecological study on the scyphozoans Aurelia aurita, Cyanea capillata and $C$. Lamarckii in the Gullmar Fjord, western Sweden, 1982 to 1986. Marine Biology 97: 541-550.

Hamner, W.M. \& Jenssen, R.M. 1974: Growth, degrowth and irreversible cell differentiation in Aurelia aurita. American Zoologist 14: 833-849.

Hamner, W.M., Hamner, P.P. \& Strand, S.W. 1994: Sun compass migration by Aurelia aurita (Scyphozoa): population persistence versus dispersal in Saanich Inlet, British Columbia. Marine Biology 119: 347-356.

Houghton, J.D.R., Doyle, T.K., Davenport, J. \& Hays, G.C. 2006: Developing a simple, rapid method for identifying and monitoring jellyfish aggregations from the air. Marine Ecology Progress Series 314: 159-170.

Ishii, H. \& Tanaka, F. 2001: Food and feeding of Aurelia aurita in Tokyo Bay with an analysis of stomach contents and a measurement of digestion times. Hydrobiologia 451: $311-320$

Kinoshita, J., Hiromi, J. \& Yamada, Y. 2006: Abundance and biomass of scyphomedusac, Aurelia aurita and Chrysaora melanaster, and Ctenophora, Bolinopsis mikado, with estimates of their feeding impact on zooplankton in Tokyo Bay, Japan. Journal of Oceanography 62: 607-615.

Larson, R.J. 1986: Water content, organic content, and carbon 
nitrogen composition of medusae from the north west Padic. Journal of Experimental Marine Biology and Ecology 99: 107-120.

Lindah1, O.\& Hernroth, L. 1983: Phyto-zooplankton community in coastal waters of Western Sweden - an ecosystem off balince? Marine Ecology Progress Series 10: 119-126.

Lucas, C. 2001: Reproduction and life history strategies of the common jellyfish, Aurelia aurita, in relation to its ambient environment. Hydrobiologia 451: 229-246,

Lucas, C. Hirst, A.G. \& Williams, J.A. 1997: Plankton dy namics and Aurelia aurita production in two contrasting eccystems: comparisons and consequences. Estuarine and Costal Shelf Science 45: 209-219.

Lucas, C. \& Williams, J.A. 1994: Population dynamics of the scyphomedusa Aurelia aurita in Southampton Water. Jownal of Plankton Research 16: 879-895.

Malej, A., 'Turlk, V., Lučić, D. \& Benović, A. 2007: Direct and indirect trophic interactions of Aurelia sp. (Scyphozoa) in a stratified marine environment (Mljet Lakes, Adriatic Sea). Marine Biology 151: 827-841.

Mills, C. E 1993: Natural mortality in NE Pacific coastal hydomedusae: grazing predation, wound healing and sencscence. Bulletin of Marine Science 53: 194-203.

Miyake, H, Iwao, K. \& Kakinuma, Y. 1997: Life history and environment of Aurelia aurita. South Pacific Studies 17: 273-285.

Moller, L.I. \& Riisgård, H.U. 2007a: Impact of jellyfish and mussels on algal blooms caused by seasonal oxygen depletion and nutrient release from the sediment in a Dauish fjord. Journal of Experimental Marine Biology and Ecology 351: 92-105.

Møller, L.If \& Riisgård, H.U. 2007b: Population dynamics, growth and predation impact of the common jellyfish Aurelia aurita and two hydromedusae, Sarsia tubulosa and Aequorea vitrina in Limfjorden (Denmark). Marine Ecology Progress Series 346: 153-165.

Olesen, N.J., Frandsen, K. \& Riisgård, H.U. 1994: Population dynamics, growth and energetics of jellyfish Aurelia aurita in a shallow fjord. Marine Ecology Progress Series 105: 9-18.

Olsson, P., Graneli, E., Carlsson, P. \& Abreu, P. 1992: Structuring of a postspring phytoplankton community by manipulation of trophic interactions. Journal of Experimental Marine Biology and Ecology 158: 249-266.

Palomares, M.L.D. \& Pauly, D. 2009: The growth of jellyfishes. Hydrobiologia 616: 11-21.

Pauly, D., Graham, W., Libralato, S., Morisette, L. \& Palomares, M.L.D. 2009: Jellyfish in ecosystems, online databases, and ecosystem models. Hydrobiologia 616: 67-85.

Pitt, K.A., Welsh, D.T. \& Condon, R.H. 2009: Influence of jellyfish blooms on carbon, nitrogen and phosphorous cycling and plankton production. Hydrobiologia 616: 133-149.

Purcell, J.E. 2009: Extension of methods for jellyfish and ctenophore trophic ecology to large-scale research. Hydrobiologia 616: 23-50.

Purcell, J.E. \& Arai, M.N. 2001: Interactions of pelagic cnidarians and ctenophores with fish: a review. Hydrobiologia 451 : $27-44$.

Purcell, J.E., Brown, E.D., Stokesbury, K., Halderson, L.H. \& Shirley, T.C. 2000: Aggregations of the jellyfish Aurelia labiata: abundance, distribution, association with age-0 walleye pollock, and behaviours promoting aggregation in Prince William Sound, Alaska, USA. Marine Ecology Progress Series 195: 145-158.

Purcell, J.E., Uye, S. \& Lo, W. 2007: Anthropogenic causes of jellyfish blooms and their direct consequences for humans: a review. Marine Ecology Progress Series 350: 153-174.

Quinn, T.J. \& Deriso, R.B. 1999: Quantitative Fish Dynamics. Oxford University Press, New York: 560 pp.

Rakow, K.C. \& Graham, W.M. 2006: Orientation and swimming mechanics by the scyphomedusa Aurelia sp. in shear flow. Limnology and Oceanography 51: 1097-1106.

Schneider, G. \& Behrends, G. 1994: Population dynamics and trophic role of Aurelia aurita medusae in the Kiel Bight and western Baltic. ICES Journal of Marine Science 51: 359-367.

Stearns, S.C. 1992: The Evolution of Life Histories. Oxford University Press: 249 pp.

Titelman, J., Riemann, L., Sørnes, T.A., Nilsen, T., Griekspoor, P. \& Bămstedt, U. 2006. Turnover of dead jellyfish: stimulation and retardation of microbial activity. Marine Ecology Progress Series 325: 43-58.

Uye, S. \& Shimauchi, H. 2005: Population biomass, feeding, respiration and growth rates, and carbon budget of the scyphomedusa Aurelia aurita in the Inland Sea of Japan. Journal of Plankton Research 27: 237-248.

Watanabe, T. \& Ishii, H. 2001: An in situ estimation of the number of ephyrae liberated from polyps of Aurelia aurita on settling plates in Tokyo Bay. Hydrobiologia 451: 247-258,

Willcox, S.W. 2006: Ecology of moon jellyfish Aurelia sp. in southern Tasmania in relation to Atlantic Salmon farming. Unpublished PhD thesis, University of Tasmania.

Willcox, S.W., Moltschaniwskyj, N.A. \& Crawford, C.M. 2008: Population dynamics of natural colonies of Aurelia sp. scyphistomae in Tasmania, Australia. Marine Biology 154: $661-670$.

Wolf, P.R. \& Dewitt, A. 2000: Elements of Photogrammetry with Applications in GIS. 3rd ed. McGraw-Hill: 608 pp.

(accepted 6 September 2011) 